\title{
Investigation of electrochemical color removal from organized industrial district (OID) wastewater treatment plants using new generation $\mathrm{Sn} / \mathrm{Sb} / \mathrm{Ni}-\mathrm{Ti}$ anodes
}

\author{
Yonar T. ${ }^{1, *}$, Shakir F. ${ }^{1}$ and Kurt A. ${ }^{2}$ \\ ${ }^{1}$ Bursa Uludag University, Faculty of Engineering, Environmental Engineering Department, Gorukle Campus, Bursa 16059, Turkey \\ 2Duzce University, Central Research Laboratory for the Scientific and Technological Supports, Konuralp Campus, 81620, Duzce, Turkey \\ Received: 24/03/2018, Accepted: 02/12/2018, Available online: 03/12/2018 \\ *to whom all correspondence should be addressed: e-mail: taneryonar@yahoo.com \\ https://doi.org/10.30955/gnj.002696
}

\begin{abstract}
In this study, the application of $\mathrm{Sn} / \mathrm{Sb} / \mathrm{Ni}$-Ti electrodes for the treatment of waste streams were investigated which is promising for ozone production by electrolysis of water because of their stability and high potential for ozone evolution reaction. These series of anodes have a high electrochemical ozone generation potential at ambient conditions (approximately up to $40 \%$ current efficiency). But using and testing of these novel anodes for real wastewater are too limited in the literature. Titanium mesh substrate coated with $\mathrm{Sn} / \mathrm{Sb} / \mathrm{Ni}$-Ti alloy was used as anode immersed in wastewater at room temperature with platinized titanium cathode. These electrodes used for COD and color removal from OID wastewater in Inegol, Bursa, Turkey. Five operational parameters were evaluated for electrochemical COD and color removal processes, such as $\mathrm{pH}$, salt content, applied voltage/current, current efficiency and contact time. Experimental results showed that after $30 \mathrm{~min}$ the electrochemical oxidation efficiency of COD and color could reach up to $98 \%$ and $99 \%$ respectively at $\mathrm{pH} 8.2$ and temperature of $25^{\circ} \mathrm{C}$ as the optimum conditions. Current density observed as the most effective parameter for COD and color removal efficiencies. The lowest energy consumption was between $10-25 \mathrm{~mA} \mathrm{~cm}^{-2}$ of current

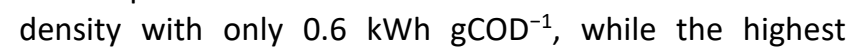
energy consumption was $100 \mathrm{~mA} \mathrm{~cm} \mathrm{~cm}^{-2}$ of current

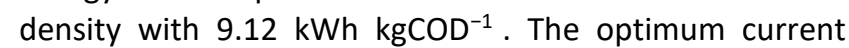
density value has been found as $50 \mathrm{~mA} \mathrm{~cm}{ }^{-2}$ with $4.05 \mathrm{kWh} \mathrm{gCOD}^{-1}$. These results were also supported with ANOVA test.
\end{abstract}

Keywords: Electrochemical oxidation, anodic oxidation, organized industrial districts, wastewater, COD, color removal, $\mathrm{Sn} / \mathrm{Sb} / \mathrm{Ni}-\mathrm{Ti}$.

\section{Introduction}

For Turkey, Organized Industrial Districts (OID) is the main and most important centralized industrial production area, including different industries. However, the structural differences that these regions show, brought about different environmental problems (Yonar et al., 2008). Evaluated OID wastewater mainly include the textile, furniture, wood and wood products producing factories wastewater. Almost $90 \%$ of incoming flow wastewaters resulted from textile factories. On the other hand, this wastewater treatment plant accepts the domestic wastewater from the city where the OID is located in Inegol, Bursa, Turkey. The flow capacity of this wastewater treatment plant in OID is approximately $100000 \mathrm{~m}^{3}$ day $^{-1}$. Overall percentages of industrial and domestic wastewater are $35 \%$ and $65 \%$, respectively. In this facility both of the industrial and domestic wastewaters are collected together and treated at the same wastewater treatment plant. The facility consists of physical and advanced biologic treatment units.

Due to the above-mentioned features, the OID wastewater have high conductivity both in terms of organic and color content. The main reason for this situation is textile industry, which is at the same time the main industrial source of wastewater. It is also natural that colored and highly conductive waters come to the area especially where dyeing and mercerization processes are carried out intensely.

The conventional wastewater treatment methods (physical and biological) used to treat these wastewaters, unfortunately, fail to be sufficient (Correira et al., 1994; Willmott et al., 1998; Vendevivere et al., 1998). Although adsorption, ion exchange, and membrane processes comprise as an alternative processes, these processes either take the contaminant mass from a medium and condense it in another medium or leave it as a denser phase to the environment, which make these processes limited in terms of application. Advanced oxidation processes (AOPs) comprise as promising treatment methods to reduce the recalcitrance and/or toxicity of industrial waste stream (Yonar et al., 2005; Üstün and Solmaz, 2006; Azbar et al., 2004). AOPs considered more advantageous compared to other treatment processes because of their complete mineralization of organic content and proper energy need usage of direct current. 
But the main problem of AOPs is their high energy requirements (Christensen et al., 2009).

Limited studies on the electrochemical degradation of synthetic textile effluent by $\mathrm{Sn} / \mathrm{Sb} / \mathrm{Ni}-\mathrm{Ti}$ anodes can be found in literature. In these studies, it is reported that $80-90 \%$ of COD and color removal is possible (Parsa and Abbasi, 2012; Zakaria and Christensen, 2014; da Silva and Jardim, 2006; Da Silva et al., 2010; Stucki et al., 1987; Cui et al., 2009; Naumczyk et al., 1996; Korbahti and Tanyolac, 2008; Nordin et al., 2013). Direct anodic oxidation is also too limited in these studies. Most of these studies conducted on synthetic dyes and different reactor and process types such as membrane electrochemical assembly type reactors, electrochemically produced ozone applied processes etc. The authors of this paper planned to conduct their study on real OID wastewater and direct anodic oxidation using $\mathrm{Sn} / \mathrm{Sb} / \mathrm{Ni}-\mathrm{Ti}$ anodes. The main reason for using $\mathrm{Sn} / \mathrm{Sb} / \mathrm{Ni}-\mathrm{Ti}$ anodes is their common and intense use on electrochemical ozone generation and investigation. Ozone production is commonly done by cold corona discharge (CCD). However, CCD remains between $2-4 \%$ in terms of current productivity (Christensen et al., 2013). From the equations 1,2 and 3 below it can be seen that ozone can be electrochemically produced by electrolysis of water also (Han et al., 2004). Ozone is formed on the surface of the anode and occurs in the water environment by overcoming the formation of oxygen. Because electrochemical formation of oxygen occurs at lower voltages (Equation 4), this voltage needs to be exceeded for the formation of ozone (Parsa and Abbasi, 2012; Da Silva and Santana, 2003). This is only possible with stable anodes.

\section{Anode Ozone Reaction}

$$
\begin{aligned}
& \mathrm{O}_{3}+6 \mathrm{H}^{+}+6 \mathrm{e}^{-} \leftrightarrow 3 \mathrm{H}_{2} \mathrm{O} \quad \mathrm{E}_{0}=1.51 \mathrm{~V} \\
& \mathrm{O}_{3}+2 \mathrm{H}^{+}+2 \mathrm{e}^{-} \leftrightarrow \mathrm{H}_{2} \mathrm{O}+\mathrm{O}_{2} \quad \mathrm{E}_{0}=2.07 \mathrm{~V}
\end{aligned}
$$

Cathode Reaction

$2 \mathrm{H}^{+}+2 \mathrm{e}^{-} \leftrightarrow \mathrm{H}_{2}$

Occurrence of Anodic Oxidation

$\mathrm{O}_{2}+4 \mathrm{H}^{+}+4 \mathrm{e}^{-} \leftrightarrow 2 \mathrm{H}_{2} \mathrm{O} \quad \mathrm{E}_{0}=1,23 \mathrm{~V}$

As mentioned above, the electrode material (anode) and the reactor structure directly affect the electrochemical ozone production. However, current efficiency is also affected by factors such as electrode morphology, cell structure, current density, electrolyte, anodic potential and temperature (Cui et al., 2009). Among these factors anodic material is one of the most important parameter, because it must be carefully chosen to achieve appreciable ozone evolution with considerable efficiency. It must have a high over potential to prohibit the oxygen evolution and be stable to strong anodic polarization in the electrolyte. Some of the common anodes encountered in literature are; $\mathrm{PbO}_{2}, \mathrm{Pt}$ (Platinum), $\mathrm{Au}$ (Gold), $\mathrm{Pb}$ (Lead) $\mathrm{SnO}_{2}$, Boron Doped Diamond and Glassy (vitreous) carbon. As can be seen from the literature, $\mathrm{Pt}$ and $\mathrm{PbO}_{2}$ anodes show current efficiency between 6.5 and $35 \%$ at low temperature $\left(<0{ }^{\circ} \mathrm{C}\right)$, while this value declines to $13 \%$ at room temperature. Here, the $\mathrm{Sn} / \mathrm{Sb} / \mathrm{Ni}-\mathrm{Ti}$ anode used in this study performs ozone production with current efficiency of about $37 \%$ at room temperature (Abbasi et al., 2014). This is another indication of the stability and strength of this anode Despite the similar efficiency that BDD anodes show, they are very expensive and far from practicability. At this point also $\mathrm{Sn} / \mathrm{Sb} / \mathrm{Ni}-\mathrm{Ti}$ anodes keep their attractiveness with their applicable prices. According to our investigations, testing of these anodes on real OID wastewater cannot be found in existing literature.

The main purpose of this work is to investigate COD and color removal efficiency on real OID wastewater treatment plant effluent in an electrochemical test system using $\mathrm{Sn} / \mathrm{Sb} / \mathrm{Ni}-\mathrm{Ti}$ anodes and to show the results.

\section{Material and method}

\subsection{Chemicals and wastewater characterization}

$\mathrm{SnCl}_{4} .5 \mathrm{H}_{2} \mathrm{O}$ (Alfa Aeser), $\mathrm{Sb}_{2} \mathrm{O}_{3}$ (Merck), NiO (Alfa Aeser), $\mathrm{HCl}$ (Merck), $\mathrm{H}_{2} \mathrm{SO}_{4}$ (Merck), ethanol (Merck), oxalic acid (Merck) were used directly without any extra purification. All solutions were prepared with Millipore Milli-Q $(18 \mathrm{M} \Omega \mathrm{cm})$ ultra-pure water. All experiments were carried out on composite samples on OID wastewater treatment plant effluents in Inegol, Bursa, Turkey. Table 1 presents the results of studied wastewater parameters.

As it can be clearly seen from Table 1, general characterization of OID wastewater is slightly lower than other OID wastewater characterization in Turkey. The main reason of this situation is the accepting of domestic wastewater to OID wastewater treatment plant which is explained in Introduction section. However, these values do not meet the Regulation on Water Pollution and Control values which OID is subject to and their purification is required. COD value in industrial wastewater is around $1000-1100 \mathrm{mg} \mathrm{L}^{-1}$, however, COD value in domestic wastewater is around $350-400 \mathrm{mg} \mathrm{L}^{-1}$. The color value is approximately $300-350 \mathrm{Pt}-\mathrm{Co}$ in industrial wastewater and 20-30 Pt-Co in domestic wastewater. Existing wastewater treatment plant on site meets the discharge standards given in Turkish Water Pollution Regulation (Table 1). From these reasons, all combined wastewater flows are treated with the physical pre-treatment units (screen, equalization and aerated grit chambers). After physical treatment, these wastewaters are treated by advanced biological treatment system which provides total nitrogen and phosphorus removal before the discharge to surface water. Table 1 provides information on system performance. The treatment system is modified VIP (Virginia Initiative Plant) (Daigger et al., 1988).

\subsection{Preparation and covering of electrodes}

The preparation of $\mathrm{Sn} / \mathrm{Sb} / \mathrm{Ni}-\mathrm{Ti}$ anodes was first performed by cutting the titanium screen substrate (Dexmet, USA) $(2.5 \mathrm{~cm} \times 2.5 \mathrm{~cm})$ and then stored in a $10 \%$ boiling oxalic acid solution to remove impurities before coating. Then the titanium screen substrates were cleaned 3 times for 10-minute intervals in an ultrasonic bath and they were dried and ready to be covered. 
Titanium screens were immersed in a pyrolysis solution containing 500/8/0.5 molar $\mathrm{Sn} / \mathrm{Sb} / \mathrm{Ni}-\mathrm{Ti}$ in order to dip coating and waited for 2 minutes. These screens removed from solution and incubated in a preheated drying oven at $105^{\circ} \mathrm{C}$ for 15 minutes and then placed in an oven which was preheated to $520^{\circ} \mathrm{C}$ for 15 minutes. This coating Table 1. Characterization of OID Wastewater Used in the Study

\begin{tabular}{|c|c|c|c|c|c|}
\hline Parameter & Unit & Value & $\begin{array}{c}\text { Discharge Limit } \\
\text { according to Turkish } \\
\text { Regulations (2004) }\end{array}$ & $\begin{array}{c}\text { Average } \\
\text { Discharge Value }\end{array}$ & $\begin{array}{c}\text { Average Removal } \\
\text { Efficiency of Existing } \\
\text { Treatment Plant \% }\end{array}$ \\
\hline COD* & $\mathrm{mg} \mathrm{l}^{-1}$ & $650 \pm 30$ & 300 & $110 \pm 10$ & \\
\hline \multicolumn{6}{|c|}{$\% 83 \pm 2.0$} \\
\hline Suspended Solids & $\mathrm{mg} \mathrm{l}^{-1}$ & $320 \pm 22$ & 100 & $20 \pm 5$ & $\% 93 \pm 3.0$ \\
\hline TKN* & $\mathrm{mg} \mathrm{l}^{-1}$ & $35 \pm 8$ & 15 & $3 \pm 0.6$ & $\% 91 \pm 0.8$ \\
\hline Total Phosphorus & $\mathrm{mg} \mathrm{l}^{-1}$ & $7 \pm 1$ & 1 & $0.3 \pm 0.05$ & $\% 95 \pm 1.2$ \\
\hline Oil \& Grease & $\mathrm{mg} \mathrm{l}^{-1}$ & $12 \pm 13$ & 10 & $1 \pm 0.4$ & $\% 91 \pm 2.2$ \\
\hline Total chrome & $\mathrm{mg} \mathrm{l}^{-1}$ & $<0.1$ & 1 & $<0.1$ & - \\
\hline Cadmium (Cd) & $\mathrm{mg} \mathrm{l}^{-1}$ & $<0.1$ & - & $<0.1$ & - \\
\hline Copper (Cu) & $\mathrm{mg} \mathrm{l}^{-1}$ & $<0.1$ & - & $<0.1$ & - \\
\hline Zinc $(Z n)$ & $\mathrm{mg} \mathrm{l}^{-1}$ & $<0.1$ & - & - & - \\
\hline Sodium $\left(\mathrm{Na}^{+}\right)$ & $\mathrm{mg} \mathrm{l}^{-1}$ & $446 \pm 53$ & - & - & - \\
\hline Potassium $\left(\mathrm{K}^{+}\right)$ & $\mathrm{mg} \mathrm{l}^{-1}$ & $23 \pm 6$ & - & - & - \\
\hline Hydroxide Alkalinity & $\mathrm{mg} \mathrm{l}^{-1}$ & 0 & - & - & - \\
\hline Carbonate Alkalinity & $\mathrm{mg} \mathrm{l}^{-1}$ & $59 \pm 4$ & - & - & - \\
\hline Bicarbonate Alkalinity & $\mathrm{mg} \mathrm{l}^{-1}$ & $418 \pm 16$ & - & - & - \\
\hline $\mathrm{pH}$ & - & $8.2 \pm 0.6$ & $6-9$ & $6-9$ & - \\
\hline Conductivity & $\mathrm{mS} \mathrm{cm}^{-1}$ & $2,2 \pm 0,4$ & - & $2.2 \pm 0.3$ & - \\
\hline Color $^{a}$ & $\mathrm{~cm}^{-1}$ & $0,88 \pm 0.12$ & $280^{b}$ & $180 \pm 15^{b}$ & - \\
\hline
\end{tabular}

COD: Chemical oxygen demand; TKN: Total kjeldahl nitrogen;

${ }^{a}$ Absorbance at $610 \mathrm{~nm}$ (SM $2120 \mathrm{C}$ )

${ }^{b}$ Color unit measures as Pt-Co in Turkish Water Pollution Control Regulation

Table 2. Analysis of variance (ANOVA) for electrochemical oxidation of organised industrial district (OID) wastewater

\begin{tabular}{|c|c|c|c|c|c|c|c|c|c|c|c|c|}
\hline & \multirow{2}{*}{\multicolumn{2}{|c|}{ Factors }} & \multicolumn{2}{|c|}{ Sum of Squares } & \multicolumn{2}{|c|}{ DF* } & \multicolumn{2}{|c|}{ Mean Sum } & \multicolumn{2}{|c|}{ Fisher Test } & \multicolumn{2}{|c|}{ P-Value* } \\
\hline & & & COD & Color & COD & Color & COD & Color & COD & Color & COD & Color \\
\hline \multirow{4}{*}{$\begin{array}{c}\text { Effect of } \\
\mathrm{NaCl}\end{array}$} & \multirow{2}{*}{$\mathrm{NaCl}$} & lines & 0,329 & 0,321 & 4 & 4 & 0,082 & 0,080 & 1,109 & 1,056 & 0,461 & 0,480 \\
\hline & & columns & 0,530 & 0,291 & 1 & 1 & 0,530 & 0,291 & 7,154 & 3,818 & 0,056 & 0,122 \\
\hline & Error & 0,297 & 0,304 & 4 & 4 & 0,074 & 0,076 & & & & & \\
\hline & Total & 1,156 & 0,916 & 9 & 9 & & & & & & & \\
\hline \multirow{4}{*}{$\begin{array}{c}\text { Effect of } \\
\mathrm{pH}\end{array}$} & \multirow{2}{*}{$\mathrm{pH}$} & lines & 13,802 & 13,826 & 6 & 6 & 2,300 & 2,304 & 0,917 & 0,920 & 0,540 & 0,539 \\
\hline & & columns & 91,294 & 92,840 & 1 & 1 & 91,294 & 92,840 & 36,404 & 37,081 & 0,001 & 0,001 \\
\hline & Error & 15,047 & 15,022 & 6 & 6 & 2,508 & 2,504 & & & & & \\
\hline & Total & 120,143 & 121,688 & 13 & 13 & & & & & & & \\
\hline \multirow{4}{*}{$\begin{array}{l}\text { Effect of } \\
\text { current } \\
\text { density }\end{array}$} & \multirow{2}{*}{$\begin{array}{l}\text { Current } \\
\text { density }\end{array}$} & lines & 2676,2 & 2680,08 & 4 & 4 & 669,04 & 670,02 & 1,0084 & 1,011 & 0,4969 & 0,4958 \\
\hline & & columns & 6553,4 & 6551,85 & 1 & 1 & 6553,4 & 6551,9 & 9,8776 & 9,89 & 0,0348 & 0,0347 \\
\hline & Error & 2653,9 & 2649,97 & 4 & 4 & 663,47 & 662,49 & & & & & \\
\hline & Total & 11883 & 11881,9 & 9 & 9 & & & & & & & \\
\hline
\end{tabular}

\subsection{Electrochemical treatability studies}

Electrochemical treatment of OID wastewater using new generation $\mathrm{Sn} / \mathrm{Sb} / \mathrm{Ni}-\mathrm{Ti}$ anodes was implemented with the aid of the apparatus shown in Figure 1.

All experiments were carried out using a $250 \mathrm{~mL}$ beaker as a reactor and the anode and cathode materials were placed mutually opposite. The $\mathrm{pH}$ value of the wastewater samples was adjusted using the $\mathrm{pH}$ meter (Cyberscan 10) during the experiments. COD measurements in experimental studies were determined by closed reflux method, titrimetric method according to Standard cycle was repeated 15 times and the final cycle temperature set for 75 minutes and the anodes were ready for use (Christensen et al., 2013; Wang et al., 2005). As a cathode, a $5 \times 5 \mathrm{~cm}$ platinized titanium electrode (NRK Electrochem) was provided and used. 
consumption per unit COD removed $\left(\mathrm{E}_{\mathrm{COD}}\right)$ was calculated according to Equation (6).

$$
E_{C O D}=\left(E_{\text {cell }} I t\right) /(V \Delta C O D)
$$

In this equation; ECOD represents energy consumption in kWh kg- ${ }^{1}$ COD, Ecell shows the electrochemical cell voltage at which the average experimental study runs in volts, I represents the current value in amperes, $t$ represents the time of electrolysis in hours, $V$ is the cell volume in $\mathrm{L}$, and $\triangle C O D$ represents the amount of COD removed between start and finishing time.

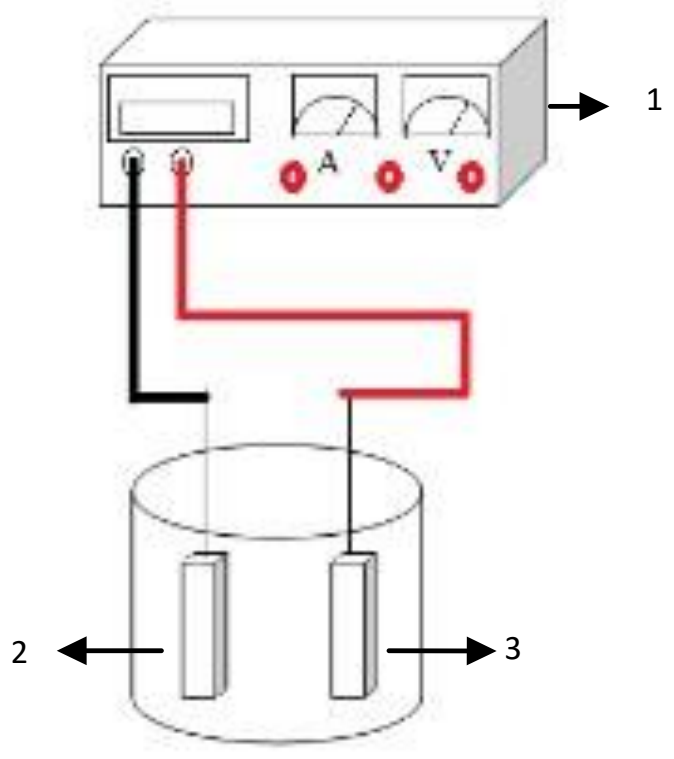

Figure 1. Experimental setup used in electrochemical ozone generation: (1) power supply (2) anode, (3) cathode

\section{Results and discussion}

\subsection{Effect of salt concentration on electrochemical} oxidation studies

In the electrochemical treatment of OID wastewater, the effect of the sodium chloride $(\mathrm{NaCl})$ concentration (as an electrolyte) on COD and color removal was tested at concentrations ranging from $0.25-1 \mathrm{~g} \mathrm{~L}^{-1}, \mathrm{pH}=8.2$ and $a$ current density $50 \mathrm{~mA} \mathrm{~cm}{ }^{-2}$. As it is well known, the salt content has a critical influence to increase the conductivity of the water treated with electrochemical processes (Parsa et al., 2014; Pillai et al., 2016). Although there are 68 factories operating in existing OID in Inegol, Bursa, Turkey, $90 \%$ of the industrial wastewater comes from textile factories ( 27 factories) using too much salt in their processes. Textile factories use very high quantities of salt (40-100 $\left.\mathrm{g} \mathrm{L}^{-1}\right)$, depending on the process being performed and the characteristics of the coloring agent to be used (Carliell et al., 1998). Although the salt concentration is reduced by additional washing processes and other aqueous processes, it can still reach very high levels. This situation is also clear in the conductivity value given in Table 1.Even when considering that, this water is being diluted with domestic wastewater, a very high conductivity value has been encountered. The conductivity at this value also shows the potential of conducting electrochemical work without the need for the salt addition. In fact, $\mathrm{Sn} / \mathrm{Sb} / \mathrm{Ni}-\mathrm{Ti}$ anodes usage first started with electrochemical ozone generation, and very successful results have obtained in this regard (Christensen et al., 2013; Wang et al., 2005). In the electrochemical oxidation studies, the formation of chloride gas and its associated hypochlorous acid, which are also important oxidants in the environment, is unavoidable with salt added (Pillai et al., 2016). However, we must not ignore the drawbacks of salt addition. The salt to be added will have an absolute extra cost. In addition, due to salt addition, an increase in the conductivity of the water to be discharged may also bring environmental problems. Because of these reasons, it is obvious that the electrochemical treatment is a very suitable method due to the conductivity of OID wastewater and the main wastewater source being textile industries.

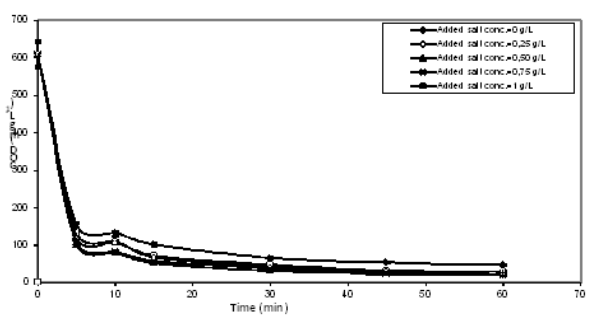

Figure 2. Effect of $\mathrm{NaCl}$ addition on COD removal $\left(\mathrm{I}=50 \mathrm{~mA} \mathrm{~cm}{ }^{-2}\right.$, $\mathrm{pH}=8.2$ )

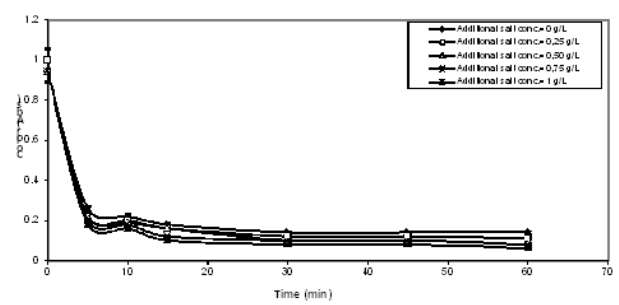

Figure 3. Effect of $\mathrm{NaCl}$ addition on Color removal $\left(I=50 \mathrm{~mA} \mathrm{~cm}^{-2}\right.$, $\mathrm{pH}=8.2$ )

\subsection{Effect of initial $\mathrm{pH}$}

$\mathrm{pH}$ has an important role for electrochemical oxidation processes. The influence of $\mathrm{pH}$ for COD and color removal efficiency tested between 3-9 and no additional $\mathrm{NaCl}$ concentration at a constant density $50 \mathrm{~mA} \mathrm{~cm}^{-2}$. However, the optimum $\mathrm{pH}$ should be determined after determining optimum electrolyte. It is observed that acidic and sometimes basic $\mathrm{pH}$ values are effective in electrochemical oxidation studies, but COD and color removal efficiency mostly observed at acidic conditions rather than basic conditions. Ozone generation capacity using new generation $\mathrm{Sn} / \mathrm{Sb} / \mathrm{Ni}-\mathrm{Ti}$ anode shows more dominance at acidic ranges (Christensen et al., 2013; Wang et al., 2005). Chlorine gas represents another 
important oxidizing agent, which is manufactured at acidic $\mathrm{pH}$ ranges on the anode surface, and tends to form hypochlorous acid at these $\mathrm{pH}$ ranges. Hydroxyl radicals generated by ozone at anode surface and hydrogen peroxide at cathode surface, at above-mentioned conditions, show dominance for COD and color removal performance. But, it is not possible to determine most effective or dominant oxidizing agent for a real OID wastewater studies.

At $\mathrm{pH}$ range 3-6, COD and color removal efficiencies show similar values. At neutral $\mathrm{pH}$, the removal efficiencies show slightly lower values than in acidic ranges with (3\%). These results supported and shown in a fairly detailed way in the literature (Khezrianjoo et al., 2016). Acidic and basic $\mathrm{pH}$ values could support the treatment of organics, theoretically. In acidic conditions hydroxyl radical (generated on anode surface) scavengers $\left(\mathrm{HCO}_{3}{ }^{-}\right.$and $\mathrm{CO}_{3}{ }^{-}$ ) can be eliminated and removal of organics can be increased. Alkaline conditions, besides their potential to manufacture chlorine gas and hypochlorite ion, they support removal efficiency of organics (Li et al., 2001; Deng and Englehardt, 2007). As it is shown at Figures 4 and 5 , better COD and color removal efficiencies can be obtained at acidic $\mathrm{pH}$ values, but neutral $\mathrm{pH}$ at 8.2 was chosen as optimum $\mathrm{pH}$ to avoid extra operational cost for $\mathrm{pH}$ adjustment.

As it is clear from both Figure 4 and Figure 5, it is not possible to define the exact $\mathrm{pH}$ influence on the electrochemical treatment of OID wastewater. However, acidic and neutral $\mathrm{pH}$ values have shown slightly better results compared to basic conditions. Briefly, further studies should be done to define the exact effect of $\mathrm{pH}$ (8.2) on the electrochemical treatment of OID wastewater, for COD and color removal efficiency.

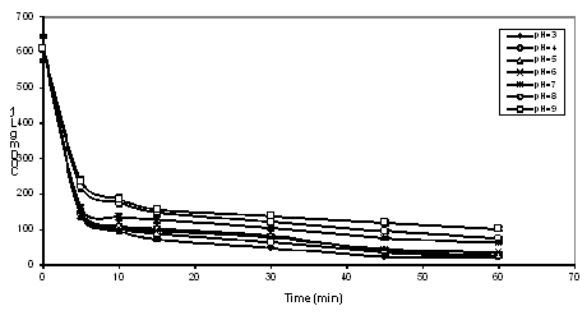

Figure 4. Effect of $\mathrm{pH}$ on COD removal $\left(\mathrm{I}=50 \mathrm{~mA} \mathrm{~cm}^{-2}\right.$, $\mathrm{NaCl}$ add. $=0 \mathrm{~g} \mathrm{~L}^{-1}$ )

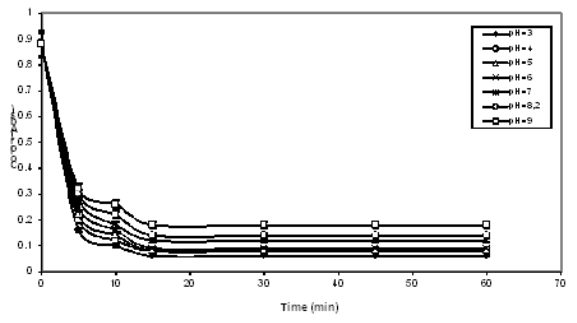

Figure 5. Effect of $\mathrm{pH}$ on Color removal $\left(\mathrm{I}=50 \mathrm{~mA} \mathrm{~cm}{ }^{-2}\right.$, $\mathrm{NaCl}$ add. $=0 \mathrm{~g} \mathrm{~L}^{-1}$ )

\subsection{Effect of current density}

Another important parameter for electrochemical treatment processes is current density, which plays an active role in reaction rate control (Deng and Englehardt, 2007). Current density detection attempts started with applying $10-100 \mathrm{~mA} \mathrm{~cm}{ }^{-2}$ at $\mathrm{pH} 8.2$ and without $\mathrm{NaCl}$ addition for COD and color removal. Increasing current density increased COD and color removal efficiencies, due to increasing of active oxidizing agent production under high current densities.

Figures 6 and 7 show that COD and color removal efficiencies declined significantly at lower current density values. At 10 and $25 \mathrm{~mA} \mathrm{~cm}^{-2}$ current density, it cannot be reached COD discharge limits. However, it is proved that it can reach COD discharge limits at $50 \mathrm{~mA} \mathrm{~cm}^{-2}$ and overcurrent densities, because at $50 \mathrm{~mA} \mathrm{~cm}{ }^{-2}$ and overcurrent density values hydraulic retention time decreases less than $10 \mathrm{~min}$, but this increase power consumption. A dramatic increase in power consumption observed by increasing current density as shown in Figure 8.

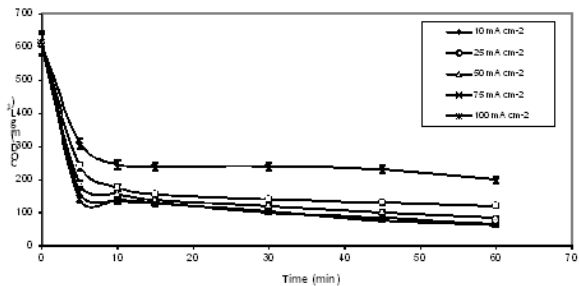

Figure 6. Effect of Current Density on COD removal $(\mathrm{pH}=8.2$, $\mathrm{NaCl}$ add. $=0 \mathrm{~g} \mathrm{~L}^{-1}$ )

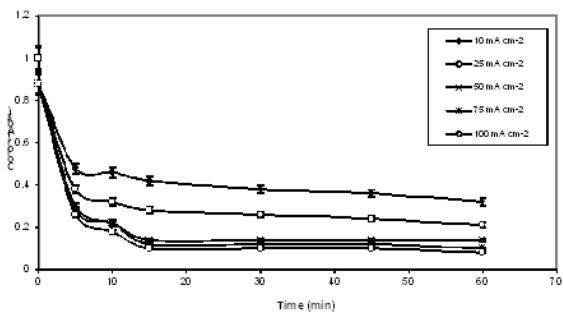

Figure 7. Effect of Current Density on Color removal $(\mathrm{pH}=8.2$, $\mathrm{NaCl}$ add. $=0 \mathrm{~g} \mathrm{~L}^{-1}$ )

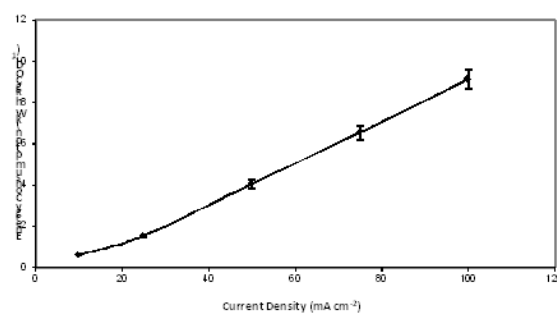

Figure 8. Power consumption values according to applied current density 


\section{Analysis of variance (ANOVA)}

For the evaluation of the importance of parameters effecting the electrochemical reactions in OID wastewater, ANOVA (analysis of variance) was used (Rosa et al., 2009). The results of ANOVA were given in Table 2 for treatment of wastewater. According to the variance analysis, variance with $95 \%$ trust, $p$-value higher than $5 \%$; $\mathrm{NaCl}(F=7,154, P$-value $=0,056$ for $\mathrm{COD}$ and $\mathrm{F}=3,818$, $\mathrm{P}$-value $=0,122$ for color) has not a big importance in COD and color removal efficiencies for electrochemical processes of industrial wastewater. $\mathrm{pH}$ parameter seems as important for both COD and color removals compared with salt addition $(F=36,404, P$-value $=0,001$ lower than $\% 5$ for $C O D$ and $F=37,081, P$-value=0,001 lower than $\% 5$ for color). Current density has a big importance $(F=9,8776$, $\mathrm{P}$-value $=0,0348$ lower than $\% 5$ for $\mathrm{COD}$ and $\mathrm{F}=9,89$, $\mathrm{P}$-value $=0,0347$ lower than $\% 5$ for color) on COD and color removal in electrochemical oxidation processes for OID wastewater. According to the ANOVA results, electrochemical oxidation process (utilization of $\mathrm{pH}$ and current density in the presence of $\mathrm{NaCl}$ ) was the most effective method for OID wastewater treatment in the experimental evaluated range.

\section{Cost evaluation}

Electrochemical oxidation process costs were calculated according to energy consumption (anode production cost, labor cost etc. were excluded) and compared with the existing treatment plant operational costs (electricity, chemical, sludge disposal etc.). According to this comparison, existing operational cost of treatment plant is around 7.2 USD cent $/ \mathrm{m}^{3}$ wastewater. Electrochemical process cost approximately seems as the less than half of this price as $\left(3,3\right.$ USD cent $\left./ \mathrm{m}^{3}\right)$. Parallel to this cost efficiency, fast oxidation and no sludge production at the end of the electrochemical oxidation are another advantages of this process against the conventional treatment processes. According to these results, from the cost side, electrochemical oxidation processes are promising for future application.

\section{Conclusions}

Investigation the efficiency of electrochemical treatment of OID wastewater using new generation $\mathrm{Sn} / \mathrm{Sb} / \mathrm{Ni}-\mathrm{Ti}$ anodes carried out in this study. Consequently;

1. $90 \%$ and $94 \%$ increase of COD and color content respectively were observed.

2. Salt addition shows an effective increase in COD and color removal efficiencies with $\% 60$ and $\% 91$ respectively.

3. Effect of $\mathrm{pH}$ seems as important on ANOVA test but the removal efficiencies during the tests observed as similar and enough for discharge COD and color limits. From these reasons, natural $\mathrm{pH}$ of wastewater can be used as optimum $\mathrm{pH}$ value because the prevention of the usage of excessive amount of acid and base and further $\mathrm{pH}$ adjustment before discharge.
4. Current density observed as the most effective parameter for COD and color removal efficiencies (in both experimental tests and ANOVA results), however, a dramatic increase in power consumption has shown as the current density increased.

According to these results, this process can be applied for the treatment of this kind of waste streams. However, $\mathrm{Sn} / \mathrm{Sb} / \mathrm{Ni}$ anodes need some times for up-scaling. On the other hand, less reaction times than traditional treatment processes mean smaller footprint for treatment plants. Briefly, electrochemical oxidation promises the cheap and fast oxidation and treatment potential. But it needs more and further studies on similar and different wastewater on the basis of pilot scale and full scale tests.

\section{Acknowledgements}

The authors acknowledge the support of the Uludag University Research Projects Department for this study (Project No. $\operatorname{OUAP}(\mathrm{MH})-2018 / 8)$.

\section{References}

Abbasi M., Soleymani A.R. and Parsa J.B. (2014), Operation simulation of a recycled electrochemical ozone generator using artificial neural network, Chemical Engineering Research and Design, 92, 2618- 2625.

APHA. (1995), Standard Methods for the Examination of Water and Wastewater, 9th edn. Washington, DC.

Azbar N., Yonar T. and Kestioğlu, K. (2004), Comparison of various advanced oxidation processes and chemical treatment methods for COD and color removal from a polyester and acetate fiber dyeing effluent, Chemosphere, 55, 35-43.

Carliell C.M., Barclay S.J., Shaw C., Wheatley A.D. and Buckley C.A., (1998), The effect of salts used in textile dyeing on microbial decolourisation of a reactive azo dye, Environmental Technology, 19, 1133-1137.

Christensen P.A., Lin W.F., Christensen H., Imkum A., Jin J.M., Li G. and Dyson C.M. (2009), Room temperature, electrochemical generation of ozone with $50 \%$ current efficiency in $0.5 \mathrm{M}$ sulfuric acid at cell voltages $<3 \mathrm{~V}$, The Journal of the International Ozone Association, 31, 287-293.

Christensen P.A., Zakaria K., Christensen H.C. and Yonar T. (2013), The effect of $\mathrm{Ni}$ and $\mathrm{Sb}$ oxide precursors, and of $\mathrm{Ni}$ composition, synthesis conditions and operating Parameters on the activity, selectivity and durability of Sb-doped $\mathrm{SnO} 2$ anodes modified with $\mathrm{Ni}$, Journal of the Electrochemical Society, 160, 405- 413.

Correira V.M., Stephenson T. and Judd S.J. (1994), Characterizastion of textile wastewater- a review, Environmental Technology, 15, 917-929.

Cui Y., Wang Y., Wang B., Zhou H., Chan K.Y. and Li X.Y. (2009), Electrochemical generation of ozone in a membrane electrode assembly cell with convective flow, Journal of Electrochemical Society, 156, 75-80.

Da Silva L.M. and Jardim, W.F. (2006), Trends and strategies of ozone application in environmental problems, Quimica Nova, 29, 310-317.

Da Silva L.M., Franco D.V., Sousa L.G. and Gonçalves, I.C. (2010), Characterization of an electrochemical reactor for the ozone 
production in electrolyte free water, Journal of Applied Electrochemistry, 40, 885-864.

Da Silva L.M., Santana M.H.P. (2003), Electrochemistry and green chemical processes: Electrochemical ozone production, Quimica Nova, 26, 880-888.

Daigger G., David G., Romm E., and Morale L. (1988), Enhanced secondary treatment incorporating biological nutrient removal, Water Pollution Control Federation Journal, 60, 1833- 1842.

Deng Y. and Englehardt J.D. (2007), Electrochemical oxidation for landfill leachate treatment, Waste Management, 27, 380388.

Han S.D., Kim J.D., Singh K.C. and Chaudry R.S. (2004), Electrochemical generation of ozone using solid polymer electrolyte-State of the art, Indian Journal of Chemistry Section A, 43, 1599-1614.

Kestioğlu K., Yonar T., Yonar G. and Şen M. (2008), Toxicity evaluation of raw physico chemically pretreated and to Fenton's oxidation applied textile and Organized Industrial Region OIR effluents on activated sludge, Fresenius Environmental Bulletin, 17, 969-977.

Khezrianjoo S. and Revanasiddappa H.D. (2016), Evaluation of kinetics and energy consumption of the electrochemical oxidation of Acid Red 73 in aqueous media, Toxicological \& Environmental Chemistry, 98, 759-767.

Korbahti B.K. and Tanyolac A. (2008), Electrochemical treatment of simulated textile wastewater with industrial components and Levafix Blue CA reactive dye: Optimization through response surface methodology, Journal of Hazardous Materials, 151, 422-431.

Li X.M., Wang M., Jiao Z.K. and Chen Z.Y. (2001), Study on electrolytic oxidation for landfill leachate treatment, China Water \&Wastewater, 17, 14-17.

Naumczyk J., Szpyrkowicz L. and Zilio-Grandi F. (1996), Electrochemical treatment of textile wastewater, Water Science Technology, 34, 17-24.

Nordin N., Amir S.F.M., Riyanto and Othman M.R. (2013), Textile industries wastewater treatment by electrochemical oxidation technique using metal plate, International Journal of Electrochemical Science, 8, 11403-11415.

Parsa J.B, Golmirzaei M. and Abbasi M. (2014), Degradation of azo dye C.I. Acid Red 18 in aqueous solution by ozoneelectrolysis process, Journal of Industrial and Engineering Chemistry, 20, 689-694.

Parsa J.B. and Abbasi M. (2012), Application of in situ electrochemically generated ozone for degradation of anthraquninone dye Reactive Blue 19, Journal of Applied Electrochemistry, 42, 435-442.

Pillai I.M.S. and Gupta A.K. (2016), Anodic oxidation of coke oven wastewater: Multiparameter optimization for simultaneous removal of cyanide, COD and phenol, Journal of Environmental Management, 176, 45-53.

Rosa J.L., Robin A., Silva M., Baldan C.A. and Peres M.P. (2009), Electrodeposition of copper on titanium wires: Taguchi experimental design approach, Journal of Materials Processing Technology, 209, 1181-1188.

Stucki S., Baumann H., Christen H.J. and Kötz R. (1987), Performance of a pressurized electrochemical ozone generator, Journal of Applied Electrochemistry, 17, 773-778.
Üstün G.E. and Solmaz S.K.A. (2006), Color and COD removal from organized industrial district (OIR) wastewater by fenton process, Fresenius Environmental Bulletin, 15, 508- 511.

Vendevivere P.C., Bianchi R. and Verstraete W. (1998), Treatment and reuse of wastewater from the textile wetprocessing industry: review of emerging technologies, Journal of Chemical Technology and Biotechnology, 72, 289302.

Wang Y.H., Cheng S.A., Chan K.Y. and Li X.Y. (2005), Electrolytic generation of ozone on antimony- and nickel-doped tin oxide electrode, Journal of the Electrochemical Society, 152, 197- 200.

Willmott N., Guthrie J. and Nelson G. (1998), The biotechnology approach to colour removal from textile effluent, Journal of the Society of Dyers and Colourists, 114, 38-41.

Yonar T. (2010), Treatability studies on traditional hand-printed textile industry wastewaters using fenton and fenton-like processes: Plant design and cost analysis, Fresenius Environmental Bulletin, 19, 2758-2768.

Yonar T., Kaplan Yonar G., Kesitoğlu K. and Azbar N. (2005), Decolorisation of textile effluent using homogeneous photochemical oxidation processes, Coloration Technology, 121, 258-264.

Zakaria K. and Christensen P.A. (2014), The use of $\mathrm{Ni} / \mathrm{Sb}-\mathrm{SnO}_{2}-$ based membrane electrode assembly for electrochemical generation of ozone and the decolourisation of reactive blue 50 dye solutions, Electrochimica Acta, 135, 11-18. 